\title{
Peirce in Germany
}

A Long Time Coming

\section{Sascha Freyberg}

\section{(2) OpenEdition \\ Journals}

Electronic version

URL: http://journals.openedition.org/ejpap/488

DOI: 10.4000/ejpap.488

ISSN: 2036-4091

Publisher

Associazione Pragma

Electronic reference

Sascha Freyberg, «Peirce in Germany », European Journal of Pragmatism and American Philosophy

[Online], VI-1 | 2014, Online since 08 July 2014, connection on 17 March 2020. URL : http://

journals.openedition.org/ejpap/488; DOI : https://doi.org/10.4000/ejpap.488

This text was automatically generated on 17 March 2020.

\section{cc) (†) $\ominus$}

Author retains copyright and grants the European Journal of Pragmatism and American Philosophy right of first publication with the work simultaneously licensed under a Creative Commons AttributionNonCommercial-NoDerivatives 4.0 International License. 


\title{
Peirce in Germany
}

\author{
A Long Time Coming
}

Sascha Freyberg

1 Although the relationship between Charles Sanders Peirce and German philosophy was a very close one, it remained rather one-sided for a long time. This story would make for a philosophical tragicomedy in three acts, but in what follows I will keep it as sober and short as possible.

2 1. As is well known, Peirce came into contact with philosophy via Kant and German Idealism (especially Schelling and Hegel). He read Kant in German from the age of 14 on and his own philosophical works - the early ones in particular - can be read as an attempt to transform transcendental philosophy in the light of the move from nominalism to realism.

While Peirce was philosophically well equipped to have a major impact on German philosophy, German philosophy was not ready for the recognition of his importance. Considering Peirce's early presence in the German-speaking world, this judgment sounds paradoxical. However, we have to understand the circumstances and reasons of this ignorance - reasons that could seem rather tragicomic in retrospect if only they were not so sad.

4 Peirce visited Germany several times and he was in personal and professional contact with German mathematicians, scientists and engineers. Still more important was his actual influence on Ernst Schröder, which was acknowledged by Schröder in the very first page of his Algebra der Logik (1891). Schröder stated that the work done by Peirce was crucial for the idea of a logical algebra or "exact logic." Therefore, with Cantor, Boole, Peano, Russell and Frege, Peirce was listed as one of the creators of modern relational algebra and logic. Given the scientifically oriented Neo-Kantian philosophical domination at the time, the reception of Peirce's philosophical work looked promising. However, he underwent an almost total omission for several decades. Klaus Oehler called this fact, which included Pragmatism and American Philosophy as a whole "the 
most significant lacunae" in the history of modern German philosophy. ${ }^{1}$ Strangely enough, one of the reasons for the ignorance towards Peirce was his association with Pragmatism, which was known via William James' lectures, which had a huge impact but negative, and even hostile, reactions. The reason was that James' concept of truth was seen as unscientific and dangerous.

Peirce's own reactions towards the popular understanding of Pragmatism of course went unheard and his semiotics were not known at all. When he died in 1914, the year in which World War I began, the philosophical scene in Germany began to change according to the dramatic historical events. Socio-economic and political changes that intervened after World War I moved the philosophical interest from Neo-Kantianism to the so-called Philosophy of Life bringing more kulturkritische, existentialistic, and psychological themes (like mood, will, place in the world, etc.) to the fore. Peirce's early fame was worth almost nothing anymore. With Bateson we could say that his work got stuck in a double bind situation - a mixture of ignorance and ill reception. Moreover, as in other countries the reception of Peirce was delayed due to the state of publication of his philosophical works. What was known in Germany of Peirce at the time came almost exclusively from James. Afterwards, it was understood only under the heading of "Pragmatism," a philosophical perspective which was strongly misunderstood for a long time in Germany, often reduced to a concept of truth as cash-value. ${ }^{2}$ Whereas Pragmatism began to find at least a small audience in the changing philosophical climate $^{3}$ the work of its founder was forgotten or never read at all. ${ }^{4}$

2. A nationalistic isolationism in philosophy, which began with World War I, was decisive for this situation as well. Although the Third World Congress for Philosophy held in 1908 in Heidelberg helped to spread discussions about Pragmatism in Germany, after the war the interest in reviving, revising or continuing the debate was gone. Who afterwards wrote on pragmatism either wanted to finish this debate (like Max Scheler in his otherwise very interesting study Erkenntnis und Arbeit) or went to know American philosophy first hand, as Gustav Müller and Edgar Wind did. They both went to the USA in the twenties. Wind was a student of Ernst Cassirer and Erwin Panofsky, and later worked at the famous Warburg Institute. In the introduction of his book Das Experiment und die Metaphysik. Zur Auflösung der kosmologischen Antinomien (Experiment and Metaphysics. Towards the Solution of the Cosmological Antinomies), which was a challenge of (Neo-) Kantianism by pragmatist methodology, Wind emphasized his Peircean point of departure. Leaving aside the works which wanted to apply Pragmatism within limited fields (as pedagogy and sociology in W. Jerusalem and philosophical anthropology in Arnold Gehlen), Wind's work was the first philosophical attempt of an independent adoption of a pragmatistic logic of research. Nevertheless, all these exceptions to the mainstream ignorance did not have any significant impact. ${ }^{5}$

7 Even when in 1934 and 1936 a couple of reviews of the first volumes of the Collected Papers appeared by Heinrich Scholz, the situation did not change. It would be more precise to say that it was not a good time for such a philosophical change. Nevertheless, in 1937 a short article on Peirce and Pragmatism appeared in the Journal of the German nobility (Deutsches Adelsblatt). The author, Jürgen von Kempski, relied heavily on Scholz's review and agreed with Scholz in saying that there was a vast potentiality in 
Peirce's writings. ${ }^{6}$ After the World War II, during which he served in the foreign ministry, Kempski kept writing a dissertation under Adorno's supervision. ${ }^{7}$ This dissertation (finished 1951) became the first monograph on Peirce and an inspiration for the future reception of Peirce. Kempski pointed out the relevance of the relation between Peirce and Kant, the consensus theory of truth, the logic of research, and abduction. In retrospect, he was not right on everything and his work on Peirce remained only as a first step; but it was a very important one. The publication of Kempski's monograph marks the beginning of a continuous German reception of Peirce. $^{8}$

8 The first volume of translation of Peirce into German was issued in 1965 (Charles S. Peirce über zeichen) edited by Elisabeth Walther and translated by some of her students. Walther took her motivation from Max Bense, who tried to follow Peirce's semiotics in an independent way. He became one of the most famous German semioticians and was the founder of a school of experimental poetry.

3. In the first three decades after World War II the recognition of Peirce grew exponentially and the interpretations improved significantly.9 The German philosophical reception of Peirce afterwards can be distinguished in roughly four, sometimes interrelated, approaches: a sociological approach understood in the broadest sense of the word, which includes communication, society, law, politics; a mathematical approach that implies logics, cybernetics, and the concept of a unified science; a metaphysical approach oriented towards the history of philosophy and ontology; and a culturological approach, which includes linguistics and media theory.

10 The sociological perspective was the first one to be developed and by far the most influential one. It is this approach that established Peirce as a canonical philosopher. Following von Kempski's hints, Karl-Otto Apel and Jürgen Habermas, both former students of E. Rothacker with connections to the Frankfurt School of Critical Theory, developed a theory of public communication and ethics of discourse for the conditions of democracy. In their theory of communicative action they stressed Peirce's turn from a priori forms of knowledge and legitimation to an a priori of the community of participants to public communication. They also underlined Peirce's idea of consensus achieved "in the long run." Apel, who edited and introduced an important translation of Peirce's work (Apel (ed.) 1967-1970) called this approach "transcendental pragmatics." Given the philosophical situation after World War II and the history of the Federal Republic of Germany with its delayed debates about historical responsibility, democratic legitimation, the student protest 1968, etc., it is by no means a coincidence that the socio-political perspective was crucial for the (West-)German reception of Peirce.

11 This became instructive also for the culturological approach, which at first met Peirce via semiotics as presented by Morris, Eco, and French semiology. An important example is the work of John Michael Krois, who translated Apel's work on Peirce into English and was a leading specialist on Ernst Cassirer. Krois wanted to integrate Peirce with Cassirer and pointed out the shortcomings of the theory of communication, and emphasized the iconic basis of communication. He proposed a philosophical iconology that studied mythological, aesthetical, and affective levels in relation with visual 
studies, or what in Germany has been called "Bildwissenschaft" (image science). In these studies culture and media theory clearly overlap with political and sociological problems. Besides, the rising of telematic media went together with the interest for Peirce's diagrammatic thought.

12 As for the philosophy of mathematics, the reception analyzes not only on the historical aspects of Peirce's work, but also the diagrammatic potentialities of his relational logic and semiotics. In this sense Max Bense tried to apply Peircean semiotics to aesthetics (1971), thereby focusing strictly on the semiotic side of Peirce. Several projects at the ZIF (Center for interdisciplinary research) in Bielefeld analyzed the potentiality of Peirce's thought for mathematical pedagogy (see Hoffmann 2003).

The most important approach for a better comprehension of Peirce's philosophy and the relation of semiotics and pragmati(ci)sm was the metaphysical one, mainly concerned with the ontology of semiotics. Going deep into the history of philosophy, Klaus Oehler, one of the pivotal figures of German semiotics, and Helmut Pape (Oehler's former student), showed the inversion of the usual relationship between sign and being in Peirce's semiotics. Pape stressed the importance of Peirce's phenomenology and edited several translations of Peirce's work, which allowed a broader audience to have access to Peirce.

14 Today the situation is very diversified. There are hermeneutical, philological, theological, and juridical studies dealing with Peirce. It should be noted, that while there is a huge number of dissertations on Peirce, there are only a few monographic books on him. In the last years there was a great, renewed interest for Peirce's epistemology, a field which was long dominated by works of analytic philosophy and critical rationalism.

Nowadays Peirce is seen as a classic philosopher. In respect to Pragmatism and Semiotics Peirce's contributions are recognized as crucial for their understanding (and development). ${ }^{10}$ However, it does not mean that these perspectives constitute the mainstream of German Philosophy in any way. In 2008, a volume on the different approaches to pragmatism and its future potentialities was issued. The title of the volume opens a significant and still provocative question: Pragmatismus - Philosophie der Zukunft?

\section{BIBLIOGRAPHY}

APEL K.-O., (1981) Charles S. Peirce: From Pragmatism to Pragmaticism, transl. by John Michael Krois, Amherst, MA, University of Massachusetts Press.

APEL K.-O., (1974), "Von Kant zu Peirce,” in Transformation der Philosophie I, Frankfurt/M., Suhrkamp. 
BENSE M., (1967), Semiotik. Allgemeine Theorie der Zeichen, Baden-Baden, Agis.

BENSE M., (1971), Zeichen und Design. Semiotische Ästhetik, Baden-Baden, Agis.

BENSE M., (1975), Semiotische Prozesse und Systeme in Wissenschaftstheorie und Design, Ästhetik und Mathematik. Semiotik vom höheren Standpunkt, Baden-Baden, Agis.

JOAS H., (1993), Pragmatism and Social Theory, Chicago, University of Chicago Press.

JOAS H., (1996), The Creativity of Action, transl. by J. Gaines and P. Keast, Chicago, University of Chicago Press.

KEMPSKI J. Von, (1952), Charles Sanders Peirce und der Pragmatismus, Stuttgart und Köln,

Kohlhammer.

KROIS J. M., (2011), Bildkörper und Körperschema. Aufsätze zur Verkörperungstheorie ikonischer Formen, Berlin, Akademie.

OEHLER K., (1993), Charles Sanders Peirce, München, Beck.

OEHLER K., (1995), Sachen und Zeichen. Zur Philosophie des Pragmatismus (a collection of articles from 1968-1994), Frankfurt/M., Klostermann.

OEHLER K., (2007), Blicke aus dem Philosophenturm. Eine Rückschau, Hildesheim et al., Olms.

PAPE H., (1989), Erfahrung und Wirklichkeit als Zeichenprozess. Charles S. Peirces Entwurf einer

Spekulativen Grammatik des Seins, Frankfurt/M., Suhrkamp.

PAPE H., (2002), Der dramatische Reichtum der konkreten Welt. Der Ursprung des Pragmatismus im Denken von Charles S. Peirce und William James, Weilerswist, Velbrück.

PAPE H., (2004), Charles Sanders Peirce zur Einführung, Hamburg, Junius.

PAPE H. (ed.), (1994), Kreativität und Logik. Charles S. Peirce und das philosophische Problem des Neuen, Frankfurt/M., Suhrkamp.

scholz H., (1936), “Anzeige der Collected Papers von Ch. S. Peirce,” Deutsche Literaturzeitung, Heft 9, 4. März 1934 und Heft 4, 26. Januar.

sCHÖNRICH G., (1990), Zeichenhandeln. Untersuchungen zum Begriff einer semiotischen Vernunft im Ausgang von Ch. S. Peirce, Frankfurt/M., Suhrkamp.

WALTHER E., (1989), Charles Sanders Peirce. Leben und Werk, Baden-Baden, Agis.

WIRTH U. (ed.), (2000), Die Welt als Zeichen und Hypothese. Perspektiven des semiotischen Pragmatismus von Charles S. Peirce, Frankfurt/M., Suhrkamp.

\section{NOTES}

1. Oehler (1981, 27): "The outbreak of World War I abruptly broke off the development of the pragmatism debate that had begun to spread through Germany in the pre-war years. The fact that it was not resumed after the war is one of the most significant lacunae in the history of German philosophy. Instead of a productive exchange of ideas there arose a long chain of misunderstandings and misconceptions of American pragmatism, originating from some of the most eminent German philosophers, and passed on with an amazingly uncritical self-assurance to others."

2. Hans Joas described the reception of Pragmatism in Germany pointedly as "A History of Misunderstandings" (1993). There were only a few explicit proponents of pragmatism mostly on 
the margins of the academic scene, like Wilhelm Jerusalem, who translated James's famous lectures (1907), Julius Goldstein, or Günther Jacoby. The latter defended Pragmatism as a theory of science and research, stressing the methodological potential over the controversies of the definitions of truth, but didn't even mention Peirce.

3. Of course it thus remained poorly understood, when taking into account that's founder was not read at all. Otherwise the ethical and epistemological ideas of Peirce would have stand in the way of a fascist reading.

4. Whereas there existed translations of James, Schiller and Dewey from early on; the first translation of Peirce appeared only in 1965.

5. Significant in this respect is the fate of Wind's book, which appeared 1934 after he emigrated with the Warburg Library to London in 1933. With Hume's words Wind said, that his book "fell dead-born from the press." It got two reviews world-wide, none of which was German (one skeptical French and one sympathetic English review written by Ernest Nagel).

6. It is important to note that semiotics played almost no role in this early reception of Peirce. Although he was recognized as a great logician, the fundamental change brought by his whole approach was not recognized.

7. In his memoirs Klaus Oehler recounted, that Adorno confessed giving the doctorate to von Kempski, because he believed him to be a very bright man, at the same time stressing to have understood "not one sentence" of the dissertation. See Oehler (2007, 139-140).

8. To be more precise: this was the beginning of West German reception, whereas the situation in East Germany was quite different. Especially in the beginning the old established prejudices could hold, intensified by the beginning of ideological warfare in the Cold War. Also Günter Jacoby, who had changed his early progressive view on Pragmatism, did not try to defend it in any way, instead adopted to the new ideological situation (again). Because of the pressure in the Soviet zone, there where only very few writings where Peirce was discussed or even mentioned by name at all; and most of it remained negative (one of the few exceptions was the cyberneticist Georg Klaus). Of course we have to keep in mind that under these ideological conditions the importance of different reading strategies was high: a critique could as well be seen as a source of information in the first place. However, contact with American Philosophy was mainly second hand, often by way of presentations given by soviet philosophers or marxists from other countries (e.g. the Polish Adam Schaff. In respect to publishing restrictions Poland and Hungary were the most liberal countries of the "Eastern Bloc"). As far as Pragmatism was concerned it went for almost all "eastern" writers as an "imperalistic" or "proto-fascist" philosophy.

9. This had influence also on the reception of pragmatism as a whole, with other main figures pushed in the background for some time. By the end of the seventies a lot of projects on pragmatism and semiotics were institionalised in one way or the other and a broader reception began.

10. Given the international orientation of researchers dealing with Peirce, there is probably no need for a German Peirce Society. The Deusche Gesellschaft für Semiotik (founded in 1979), a part of the International Society of Semiotics, incorporates some of the more application oriented studies of Peircean concepts, sometimes lacking philosophical involvement. It nevertheless carries on an interesting journal (Zeitschrift für Semiotik). 


\section{AUTHOR}

SASCHA FREYBERG

Freie Universität Berlin, Deutschland

sascha.freyberg[at]gmail.com 